\title{
The role of Inositol 1,4,5 triphosphate kinase $C$ in the pathogenesis of Kawasaki disease
}

\author{
Vahid Khajoee ${ }^{1 *}$, Rae SM Yeung ${ }^{1,2}$ \\ From 18th Pediatric Rheumatology European Society (PReS) Congress \\ Bruges, Belgium. 14-18 September 2011
}

\section{Background}

Kawasaki disease (KD) is a childhood multisystemic vasculitis resulting in the development of coronary aneurysms. Functional polymorphism in Inositol 1,4,5-triphosphate kinase $C$ (ITPKC) has recently been identified and linked to KD susceptibility and severity. ITPKC acts as a negative regulator of $\mathrm{T}$-cell activation through the inhibition of $\mathrm{Ca}^{2+} /$ Nuclear factor of activated T-cells (NFAT) signalling pathway. Lactobacillus casei cell wall extract induced coronary arteritis is an animal model of KD dependent on superantigenic activity.

\section{Objective}

To determine the role of ITPKC in the pathogenesis of KD.

\section{Methods}

To assess the role of ITPKC in lymphocyte activation, mouse splenocytes were stimulated with superantigen and T-cell proliferation, cytokines production, $\mathrm{Ca}^{2+}$ flux and ITPKC protein expression were measured by ${ }^{3} \mathrm{H}$ thymidine, ELISA, flow cytometry, and Western blot, respectively. To confirm the results in a human system, lymphocyte activation was determined in a human cell line after siRNA knockdown.

\section{Results}

ITPKC was upregulated at both mRNA and protein levels by mouse splenocytes following superantigen stimulation. Cyclosporin A inhibition of $\mathrm{Ca}^{2+}$ /NFAT signalling abolished T-cell proliferation and cytokine production following superantigen activation. ITPKC knockdown in

\footnotetext{
* Correspondence: vahid.khajoee@sickkids.ca

${ }^{1}$ Cell Biology Program, Hospital for Sick Children Research Institute, University of Toronto, Toronto, Ontario, Canada

Full list of author information is available at the end of the article
}

superantigen activated human lymphocyte cell line could not completely inhibit cytokine production or $\mathrm{Ca}^{2+}$ flux.

\section{Conclusion}

Although ITPKC and the $\mathrm{Ca}^{2+} / \mathrm{NFAT}$ signalling pathway were activated in lymphocytes following superantigen stimulation, inhibition of ITPKC was not able to alter lymphocyte activation or $\mathrm{Ca}^{2+}$ flux pointing to overlapping or compensatory pathways. These findings may account for the conflicting reports on the association between ITPKC polymorphisms and KD in different ethnicities.

\section{Author details}

${ }^{1}$ Cell Biology Program, Hospital for Sick Children Research Institute, University of Toronto, Toronto, Ontario, Canada. ${ }^{2}$ Departments of Pediatrics, Immunology, and Medical Sciences, University of Toronto, Toronto, Ontario, Canada.

Published: 14 September 2011

doi:10.1186/1546-0096-9-S1-P295

Cite this article as: Khajoee and Yeung: The role of Inositol 1,4,5

triphosphate kinase $C$ in the pathogenesis of Kawasaki disease. Pediatric

Rheumatology 2011 9(Suppl 1):P295.

Submit your next manuscript to BioMed Central and take full advantage of:

- Convenient online submission

- Thorough peer review

- No space constraints or color figure charges

- Immediate publication on acceptance

- Inclusion in PubMed, CAS, Scopus and Google Scholar

- Research which is freely available for redistribution 